DR. DANILO SILVA ALMEIDA (Orcid ID : 0000-0002-9115-8940)

Article type : Research Paper

\title{
Can tropical grasses grown as cover crops improve soil
}

\section{phosphorus availability?}

\author{
Danilo S. Almeida ${ }^{1}$ *, Daniel Menezes-Blackburn ${ }^{2,3}$, Kassiano F. RochA $^{1}$, Murilo de \\ SOUZA $^{1}$, HAO ZHANG $^{2}$, PHILIP M. HAYGARTH $^{2}$, CiRO A. ROSOLEM $^{1}$ \\ ${ }^{1}$ São Paulo State University, Department of Crop Science, Botucatu, 18610-307, Brazil \\ ${ }^{2}$ Lancaster University, Lancaster Environment Centre, Lancaster, LA1 4YQ, UK \\ ${ }^{3}$ Sultan Qaboos University, Department of Soils, Water and Agricultural Engineering, PO \\ Box 34, Al-khod 123, Sultanate of Oman
}

*Corresponding Author: Danilo S. Almeida (E-mail: daniloalmeidaagronomia@gmail.br)

Running Title: Tropical grasses and soil phosphorus availability

\section{Summary}

Tropical grasses grown as cover crops can mobilize phosphorus $(\mathrm{P})$ in soil and have been suggested as a tool to increase soil $\mathrm{P}$ cycling and bioavailability. The objective of this study was to evaluate the effect of tropical grasses on soil P dynamics, lability, desorption kinetics and bioavailability to soybean, specifically to test the hypothesis that introducing grass species in the cropping system may affect soil $\mathrm{P}$ availability and soybean development according to soil $\mathrm{P}$ concentration. Three grass species: ruzi grass (Urochloa ruziziensis),

This article has been accepted for publication and undergone full peer review but has not been through the copyediting, typesetting, pagination and proofreading process, which may lead to differences between this version and the Version of Record. Please cite this article as doi: $10.1111 /$ sum. 12439

This article is protected by copyright. All rights reserved. 
palisade grass (Urochloa brizantha), and Guinea grass (Megathyrsus maximus) were grown in soils with contrasting $\mathrm{P}$ status. Soybean was grown after grasses to assess soil $\mathrm{P}$ bioavailability. Hedley $\mathrm{P}$ fractionation, microbial biomass $\mathrm{P}$, phytase-labile $\mathrm{P}$, and diffusive gradient in thin films were determined, before and after cultivation. It was found that grasses re-mobilized soil $\mathrm{P}$, reducing the concentration of recalcitrant $\mathrm{P}$ forms. The effect of grasses on changing the $\mathrm{P}$ desorption kinetics parameters did not directly explain the observed variation on P bioavailability to soybean. Grasses and microorganisms solubilize recalcitrant organic $\mathrm{P}\left(\mathrm{P}_{\mathrm{o}}\right)$ forms and tropical grasses grown as cover crops increased $\mathrm{P}$ bioavailability to soybean mainly due to the supply of $\mathrm{P}$ by decomposition of grass residues in low-P soil. However, no clear advantages in soybean $\mathrm{P}$ nutrition were observed when in rotation with these grasses in high-P soil. This study indicates that further advantages in soybean $\mathrm{P}$ nutrition after tropical grasses may be impeded by phytate, which is not readily available to plants.

Keywords: Urochloa ruziziensis, Urochloa brizantha, Megathyrsus maximus, Cover crops, Phosphorus pools, Organic phosphorus.

\section{Introduction}

Phosphorus (P) uptake by cash crops has been observed to increase after growing cover crops, such as Lablab purpureus and Lupinus albus, due to release of $\mathrm{P}$ by the straw decomposition (Horst et al., 2001) or due to an increase in soil P bioavailable pools (Calegari et al., 2013). Recently, it has been shown that ruzi grass (Urochloa ruziziensis) and palisade grass (Urochloa brizantha) can mobilize and take up soil recalcitrant $\mathrm{P}$ bound to iron $(\mathrm{Fe})$ and aluminum (Al) (Merlin et al., 2015). Under no-till, ruzi grass grown in the soybean (Glycine max) off-season enhances $\mathrm{P}$ cycling decreasing residual-P concentration in deeper 
soil layers (Almeida \& Rosolem, 2016). Cover crops may increase soil P availability to subsequent cash crops through an increase in the labile $\mathrm{P}$, decrease of soil organic $\mathrm{P}\left(\mathrm{P}_{\mathrm{o}}\right)$, increase of $\mathrm{P}$ desorption kinetics, or by a simple release of readily available $\mathrm{P}$ during its decomposition and mineralization.

Organic acids exuded by roots may compete with $\mathrm{P}$ for adsorption sites and complex metals, inducing $\mathrm{P}$ desorption and solubilization in soil, and may also act as energy source to microorganisms (Hinsinger, 2001). Soil microbial biomass plays two main roles on soil $\mathrm{P}$ dynamics, not only as a main driver in mineralization of recalcitrant $\mathrm{P}_{\mathrm{o}}$, but also in the inorganic $\mathrm{P}\left(\mathrm{P}_{\mathrm{i}}\right)$ immobilization (Richardson et al., 2001). The $\mathrm{P}_{\mathrm{o}}$ is mainly composed of orthophosphate monoesters (Stutter et al., 2015), which can be classified as labile monoesters such as the breakdown products of DNA, and non-labile monoesters such as inositol phosphates (Shears \& Turner, 2007). Phytate is an inositol phosphate that can account for more than $70 \%$ of total $\mathrm{P}_{\mathrm{o}}$ (Canellas et al., 2004), being the least bioavailable $\mathrm{P}_{\mathrm{o}}$ form due to its strong affinity to soil particles and fast precipitation as insoluble forms (Berg \& Joern, 2006).

According to Syers et al. (2008), the factors controlling soil P availability to plants are the soil solution $\mathrm{P}$ concentration and soil $\mathrm{P}$ buffer capacity. The diffusion of $\mathrm{P}$ into roots is governed by the $\mathrm{P}$ concentration gradient between the bulk soil solution and the concentration next to the root surface (Roose \& Kirk, 2009). The strong soil P adsorption capacity by Fe and $\mathrm{Al}$ oxides in highly weathered soils results in lower soil $\mathrm{P}$ solution concentration, and reduce the P diffusion flux (Raghothama \& Karthikeyan, 2005). However, growing adapted species in low-P soils may affect the P resupply by the soil solid phase due to changes in the soil P pools (Almeida et al., 2018).

This article is protected by copyright. All rights reserved. 
A closer look into $\mathrm{P}$ dynamics in the rhizosphere of tropical grasses is needed to achieve a better understanding of the potential of these grasses in inducing $\mathrm{P}$ cycling. The objective of this study was to evaluate the effect of tropical grasses on soil $\mathrm{P}$ dynamics and availability to soybean as a subsequent crop, to test the hypothesis that introducing grass species in the cropping system may affect soil $\mathrm{P}$ availability to soybean according to soil $\mathrm{P}$ concentration. Namely, this work aims to unravel how different cover crop grasses will affect: a) soil $\mathrm{P}$ pool distribution; b) $\mathrm{P}_{\mathrm{i}}$ lability and desorption kinetics; and c) $\mathrm{P}_{\mathrm{o}}$ dynamics, especially those involving phytate.

\section{Materials and methods}

The approach used a greenhouse experiment with soil taken from plots of a long-term experiment in Botucatu, Brazil (22 $50^{\prime} 00^{\prime \prime} \mathrm{S} ; 4^{\circ} 25^{\prime} 31^{\prime \prime} \mathrm{W}$; altitude of $806 \mathrm{~m}$ ), where soybean [Glycine max (L.) Merrill] had been cropped since 1998. The soil is a Rhodic Hapludox (Soil Survey Staff, 2014) with $67 \%$ sand and $21 \%$ clay. For the experiment, soil was collected from the $0-0.20 \mathrm{~m}$ depth, and accommodated in $9 \mathrm{~L}$ plastic pots.

The experimental design was a $2 \times 3$ factorial in randomized complete blocks, and two control treatments, with eight replications. The treatments consisted of two soil P levels, three grass species, and non-cultivated controls without grasses. The soil P levels were characterized as low, for the soil that did not have P fertilizer added; and high, which had received a total of $305 \mathrm{~kg} / \mathrm{ha}$ of $\mathrm{P}$ as triple superphosphate (TSP) from 2001 to 2014 . The grass species were ruzi grass [Urochloa ruziziensis (R. Germ. and C.M. Evrard) Morrone and Zuloaga], palisade grass [U. brizantha (A. Rich.) R.D. Webster], and Guinea grass [Megathyrsus maximus (Jacq.) B.K. Simon and S.W.L. Jacobs].

This article is protected by copyright. All rights reserved. 


\section{Conducting the experiments}

Five grass plants were grown in pots for 60 days and then desiccated with glyphosate, simulating the usual desiccation management in field. Pots from four replicates were disassembled to evaluate grass shoots, roots, and rhizosphere soil, while the pots from remaining four replicates were maintained intact after grass desiccation. Rhizosphere soil was considered the soil adhered to the roots, and was gently separated by hand-shaking. Fifteen days after desiccation, grass shoots from the intact pots were chopped into pieces and accommodated on the soil surface, and 6 seeds of soybean were sown. After thinning, two soybean plants were grown per pot up to flowering.

\section{Soil chemical characterization}

For all soil analyses, soil samples were air-dried and passed through a 2-mm sieve. The soils were initially analyzed for chemical characterization (Table 1). Soil available P was extracted using pearl resin (Resin-P), as well as calcium $(\mathrm{Ca})$, magnesium $(\mathrm{Mg})$, and potassium $(\mathrm{K})$, according to Raij et al. (2001). Soil $\mathrm{pH}$ in $\mathrm{CaCl}_{2}$, soil organic matter (SOM), potential acidity $(\mathrm{H}+\mathrm{Al})$, and cation exchange capacity (CEC) were determined according to Raij et al. (2001).

\section{Phosphorus fractionation}

Soil P fractionation was performed according to the method of Hedley et al. (1982) with the modifications proposed by Condron \& Goh (1989). Briefly, $0.5 \mathrm{~g}$ of air-dried soil was subjected to the following sequential extraction: anion exchange resin (AER) strips; sodium bicarbonate $\left(\mathrm{NaHCO}_{3}\right), 0.5 \mathrm{~mol} / \mathrm{L}$; sodium hydroxide, $0.1 \mathrm{~mol} / \mathrm{L}(0.1 \mathrm{NaOH})$; hydrochloric acid, $1 \mathrm{~mol} / \mathrm{L}(\mathrm{HCl})$; and sodium hydroxide, $0.5 \mathrm{~mol} / \mathrm{L}(0.5 \mathrm{NaOH})$. After extraction, $0.1 \mathrm{~g}$ of the soil was subjected to digestion $\left(\mathrm{HNO}_{3}+\mathrm{HClO}_{4}\right)$ for the extraction of residual P. In acid extracts obtained with $\mathrm{AER}, \mathrm{HCl}$, and nitroperchloric digestion, the following $\mathrm{P}$ fractions 
were analyzed: AER-P, HCl-P, and Residual-P, respectively. The alkaline extracts were divided into two aliquots. In the first aliquot of each alkaline extract, the following inorganic $\mathrm{P}\left(\mathrm{P}_{\mathrm{i}}\right)$ fractions were obtained: $\mathrm{NaHCO}_{3}-\mathrm{P}_{\mathrm{i}}, 0.1 \mathrm{NaOH}-\mathrm{P}_{\mathrm{i}}$, and $0.5 \mathrm{NaOH}-\mathrm{P}_{\mathrm{i}}$. The second aliquot was subjected to digestion with ammonium persulfate and sulfuric acid in an autoclave to determine the total $\mathrm{P}\left(\mathrm{P}_{\mathrm{t}}\right)$ content. The molybdate unreactive $\mathrm{P}$ was calculated as the difference between $\mathrm{P}_{t}$ and $\mathrm{P}_{\mathrm{i}}$ and was here termed as organic $\mathrm{P}\left(\mathrm{P}_{\mathrm{o}}\right)$. Thus, the following extracted $\mathrm{P}$ fractions were obtained: $\mathrm{NaHCO}_{3}-\mathrm{P}_{\mathrm{t}}, \mathrm{NaHCO}_{3}-\mathrm{P}_{\mathrm{o}}, 0.1 \mathrm{NaOH}-\mathrm{P}_{\mathrm{t}}, 0.1 \mathrm{NaOH}-\mathrm{P}_{\mathrm{o}}$, 0.5 NaOH- $\mathrm{P}_{\mathrm{t}}$, and $0.5 \mathrm{NaOH}-\mathrm{P}_{\mathrm{o}}$. An analytical triplicate was used throughout the fractionation analysis. The sum of all extracted $\mathrm{P}$ fractions was labeled Total-P. The data was expressed as the change $(\Delta)$ for each $\mathrm{P}$ fraction between the samples collected before (time 0 ) and after grass growth.

\section{Phytase labile phosphorus}

Phytase labile $\mathrm{P}$ was assayed in soil extracts with $0.25 \mathrm{~mol} / \mathrm{L} \mathrm{NaOH}$ plus $0.05 \mathrm{~mol} / \mathrm{L}$ ethylenediaminetetraacetic acid (NaOH-EDTA). Samples of $2 \mathrm{~g}$ of air dried soil were extracted with $20 \mathrm{~mL}$ of extractant on a reciprocal shaker for 16 h. Phytase labile $\mathrm{P}$ ( $\left.\mathrm{P}_{\text {Phy-lab }}\right)$ was determined using a commercially available phytase (Natuphos, EC 3.1.3.8; BASF SE, Ludwigshafen, Germany). Briefly, soil extracts $(100 \mu \mathrm{L})$ were combined with $100 \mu \mathrm{L}$ of phytase $(100 \mathrm{nKat} / \mathrm{mL})$ diluted in a buffer $(50 \mathrm{mmol} / \mathrm{L}$ acetate, $\mathrm{pH} 5.5)$ and incubated at $37^{\circ} \mathrm{C}$ for $16 \mathrm{~h}$. Organic $\mathrm{P}$ hydrolysable by phytases was inferred by the difference of $\mathrm{P}_{\mathrm{i}}$ content measured after the incubation of samples with phytase and samples with denatured phytase.

Similarly, to the fractionation analysis, $\mathrm{P}_{\mathrm{t}}, \mathrm{P}_{\mathrm{i}}$ and $\mathrm{P}_{\mathrm{o}}$ extracted by $\mathrm{NaOH}-\mathrm{EDTA}$ were also assayed. The difference between $\mathrm{NaOH}-E D T A-\mathrm{P}_{\mathrm{t}}$ and $\mathrm{NaOH}-\mathrm{EDTA}-\mathrm{P}_{\mathrm{i}}$ corresponds to $\mathrm{NaOH}-\mathrm{EDTA}-\mathrm{P}_{\mathrm{o}}$. The change $(\Delta)$ in these parameters to the initial concentration and the changes in percentage of $\mathrm{P}_{\text {phy-lab }}$ in relation to $\mathrm{P}_{\mathrm{o}}$ were calculated.

This article is protected by copyright. All rights reserved. 


\section{Microbial biomass phosphorus}

The microbial biomass P (MBP) was determined according to Stutter et al. (2015) and references cited therein. Samples of $80 \mathrm{~g}$ of soil were placed in a container and wetted with ultra-pure Milli-Q (MQ) water to approximately 50\% water holding capacity to re-establish microbial activity, and incubated for $72 \mathrm{~h}$. After incubation, the soil slurry was prepared by adding MQ water and mixing the soil until maximum retention was reached. Quadruplicates of soil slurry ( $1 \mathrm{~g}$ of dry weight equivalent) were extracted for $16 \mathrm{~h}$ in $10 \mathrm{~mL}$ of MQ water with AER strips either with or without addition of $0.4 \mathrm{~mL}$ hexanol. After $16 \mathrm{~h}$, the resins were eluted with $0.5 \mathrm{~mol} / \mathrm{L} \mathrm{HCl}$ and the concentration of $\mathrm{P}$ was measured. The MBP was

estimated as the difference between samples extracted with and without hexanol. A correction factor to account for sorption of $\mathrm{P}$ to soil solid phase was determined from soil samples spiked with $20 \mathrm{mg} / \mathrm{g}$ of $\mathrm{P}$.

\section{Diffusive gradient and equilibrium in thin films}

Soil labile $\mathrm{P}$ was measured using diffusive gradient in thin films (DGT) and soil solution $\mathrm{P}$ was assessed using diffusive equilibrium in thin films (DET) as in Menezes-Blackburn et al. (2016b) and references cited therein. A binding layer containing ferrihydrite was used for the DGT test. More information about the preparation of the diffusive and binding layer are published in Menezes-Blackburn et al. (2016b).

The DET devices were deployed in soil slurry prepared as in MBP analysis. On the next day, the DGT devices were deployed for $48 \mathrm{~h}$. The DGT and DET devices were deployed in duplicates for each experimental replicate. The diffusive and binding layers were eluted in $0.5 \mathrm{~mL}$ of $\mathrm{H}_{2} \mathrm{SO}_{4}$ solution, $0.25 \mathrm{~mol} / \mathrm{L}$. The concentration of $\mathrm{P}$ in the diffusive layer of DET devices $\left(\mathrm{P}_{\mathrm{DET}}\right)$ is expressed as the equilibrium concentration to soil solution $\mathrm{P}$. The 
concentration of labile $\mathrm{P}\left(\mathrm{P}_{\mathrm{DGT}}\right)$ at the surface of the DGT devices was calculated using eq. 1 (Zhang \& Davison, 1995).

$$
\mathrm{P}_{\mathrm{DGT}}=\frac{\mathrm{M} \Delta \mathrm{g}}{\mathrm{DAt}}
$$

where $\mathrm{M}$ is the accumulated $\mathrm{P}$ mass in the binding layer, $\mathrm{A}$ is the surface area of the DGT sampling window, $\mathrm{t}$ is the deployment time, $\Delta \mathrm{g}$ is the total thickness of the diffusive gel layer and the filter membrane, and $\mathrm{D}$ is the diffusion coefficient of $\mathrm{P}$ in the diffusive gel. The $\mathrm{P}_{\mathrm{DGT}}$ could be converted to an effective concentration ( $\left.\mathrm{P}_{\mathrm{E}}\right)$ using eq. 2 (Zhang et al., 2001).

$$
P_{E}=\frac{P_{D G T}}{R_{\text {diff }}}
$$

The diffusive only ratio ( $\left.\mathrm{R}_{\text {diff }}\right)$ between $\mathrm{P}_{\mathrm{DGT}}$ and soil solution $\mathrm{P}\left(\mathrm{P}_{\mathrm{DET}}\right)$ was calculated using a dynamic numerical model (DIFS) (Harper et al., 2000). The ratio (R) of measured $\mathrm{P}_{\mathrm{DGT}}$ concentration to the $\mathrm{P}_{\mathrm{DET}}$ was calculated as in eq. 3 .

$$
\mathrm{R}=\frac{\mathrm{P}_{\mathrm{DGT}}}{\mathrm{P}_{\mathrm{DET}}}
$$

The relative resupply from solid phase $\left(R-R_{\text {diff }}\right)$ was calculated subtracting the $R_{\text {diff }}$ from the $\mathrm{R}$ ratio. Using the DIFS model, the $\mathrm{T}_{\mathrm{c}}$ was also obtained.

\section{Plant analysis}

The grass biomass was harvested, and roots were separated from shoots. Soybean was harvested at flowering (after 53 days of emergence). The remaining grass straw on the soil surface was also collected. All plant material was dried at $65^{\circ} \mathrm{C}$ to determine dry mass. Concentration of $\mathrm{P}$ in plant materials was determined according to Jackson (1973). The $\mathrm{P}$ released from grass straw was measured by the difference on $\mathrm{P}$ accumulated in the grass shoot right after desiccation and 53 days after. The decomposition of grass straw was based on the difference of shoot dry weight of grass after desiccation and after 53 days.

This article is protected by copyright. All rights reserved. 


\section{Statistical analysis}

Data were subjected to ANOVA considering a $2 \times 3$ factorial in randomized complete blocks, with four replications, and means were compared using Tukey's test $(p<0.05)$. To allow a better comparison of the grass effect, the control treatment was not included in ANOVA and Tukey's test. Instead, a second ANOVA was performed, considering a $2 \times 4$ factorial in randomized complete blocks, with four replications, and Dunnett's test $(p<0.05)$ was used to compare the significance of the difference between different treatments and the respective controls. All the statistical analyses were performed using SAS software (SAS Inst., North Carolina, U.S.).

\section{Results and discussion}

\section{Soil phosphorus pools: distribution and availability}

The calculated change $(\Delta)$ in soil $\mathrm{P}$ concentrations in each pool before and after grass cultivation can be interpreted as a decrease in the $\mathrm{P}$ pool (negative $\Delta$ values). This indicates that $\mathrm{P}$ was transferred to other pools or taken up by the grasses, while an increase in the $\mathrm{P}$ pool (positive $\Delta$ values) indicates that $\mathrm{P}$ was accumulated into this pool (Table 2). Great changes in $\mathrm{P}$ pools were observed, since the $\Delta$ was obtained from the rhizosphere soil, a particular region where the effect of roots and microorganisms is much higher than in the bulk soil.

Growing grasses depleted $\mathrm{P}_{\mathrm{i}}$ in the firsts extracts of the sequential fractionation $\left(\mathrm{AER}-\mathrm{P}, \mathrm{NaHCO}_{3}-\mathrm{P}_{\mathrm{i}}\right.$ ) (Table 2), which are considered the most available soil $\mathrm{P}$ fractions (Cross \& Schlesinger, 1995). Depletion of these P fractions had also been observed in the rhizosphere of Zea mays, Lablab purpureus, and Mucuna pruriens (Horst et al., 2001). The decrease in Resin-P in the control treatments with high $\mathrm{P}$ level results from the equilibrium between soil solution $\mathrm{P}$ and $\mathrm{P}$ in the solid phase. Soil $\mathrm{P}_{\mathrm{i}}$ equilibrium is a dynamic combination

This article is protected by copyright. All rights reserved. 
of sorption and desorption processes, which transfer $\mathrm{P}_{\mathrm{i}}$ between the solid and solution phases. The control treatment with low P level had a small increase in AER-P; possibly, this was a consequence of the MBP mineralization (Macklon et al., 1997).

The sum of $\mathrm{P}_{\mathrm{o}}$ fractions extracted with $\mathrm{NaHCO}_{3}, 0.1$ and $0.5 \mathrm{NaOH}$ accounted for $46 \%$ to $56 \%$ of total soil $\mathrm{P}$ fractions when Residual-P was not considered. Organic $\mathrm{P}$ accounted for approximately $60 \%$ and $54 \%$ of total soil P extracted with NAOH-EDTA, for soils with low and high $\mathrm{P}$ levels, respectively. The high proportions of $\mathrm{P}_{\mathrm{o}}$ in the soil suggest the importance of the mobilization of this fraction to improve plant $\mathrm{P}$ nutrition (Rodrigues et al., 2016).

The simple incubation of moist uncultivated soil of the control treatments at greenhouse conditions caused a significant change in $\mathrm{P}_{\mathrm{o}}$ pools, indicating an active microbial role in redistributing these fractions. These uncultivated control samples behaved remarkably different at different $\mathrm{P}$ levels: while in the low-P soils there was a movement from residual $\mathrm{P}$ towards more labile pools, the opposite was observed at high $\mathrm{P}$ levels, where $\mathrm{P}$ was continuously fixed into this less labile pool (Residual-P). Conversely, the presence of plants changed these trends, causing a depletion of Residual-P and an increase of alkali soluble $\mathrm{P}_{\mathrm{o}}$ fractions in the rhizosphere (Table 2). The HCl-extractable $\mathrm{P}$ was decreased in the low-P soil and it was increased in the high-P soil compared with the initial concentrations, regardless of the effect of grass cultivation.

Despite the fact that Residual-P may be considered as a combination of inorganic and organic stable $\mathrm{P}$ forms strongly associated with the mineral fraction, $\mathrm{P}$ re-mobilization was mainly observed in Residual-P due to grass cultivation. Several studies have shown that Residual-P can be depleted by plant uptake (Almeida et al., 2018).

This article is protected by copyright. All rights reserved. 
When grasses were grown, there was an increase in $\mathrm{P}_{\mathrm{o}}$ pools extracted with $\mathrm{NaHCO}_{3}$, and $0.5 \mathrm{~mol} / \mathrm{L} \mathrm{NaOH}$ (Table 2), which is in accordance with the observations in field studies with crop rotations under no-till (Almeida \& Rosolem, 2016; Rodrigues et al., 2016), and in pot studies (Horst et al., 2001). However, for soil with high $\mathrm{P}$ level, the $\mathrm{P}_{\mathrm{o}}$ extracted with $0.1 \mathrm{~mol} / \mathrm{L} \mathrm{NaOH}$ was decreased by the grasses. According to Beck \& Sanchez (1994), $\mathrm{NaOH}$-extractable $\mathrm{P}_{\mathrm{o}}$ is an important source of $\mathrm{P}$ in weathered soils that have not had P fertilizer added, which may have contributed to the decrease of this fraction observed in the soil with high P level in the present study. Studies have shown that phytate content in soils is frequently found to be major fraction of $\mathrm{P}_{\mathrm{o}}$ and may account for the most part of total $\mathrm{P}_{\mathrm{o}}$ (Canellas et al., 2004), however here the $\mathrm{P}_{\text {Phy-lab }}$ was approximately $23 \%$ and $13 \%$ of $\mathrm{P}_{\mathrm{o}}$ extracted with NAOH-EDTA in the present study, for the low- and high-P soils, respectively. Chapuis-Lardy et al. (2001) reported that in Cerrado oxisols $\mathrm{P}_{\mathrm{o}}$ appears to be mainly in form of stable monoesters in the $\mathrm{NaHCO}_{3}$ and $0.5 \mathrm{NaOH}$ extracts. Therefore, the increase in $\mathrm{P}_{\mathrm{o}}$ observed in $\mathrm{NaHCO}_{3}$ and $0.5 \mathrm{NaOH}$ extracted from $\mathrm{P}$ fractionation in this experiment may be

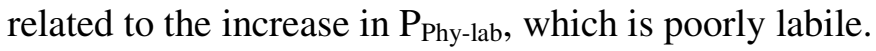

Since the $\mathrm{P}_{\text {Phy-lab }}$ increased in all the treatments, soil microorganisms could have desorbed the recalcitrant $\mathrm{P}_{\mathrm{o}}$ including phytate, increasing $\mathrm{P}_{\text {Phy-lab}}$, where no changes in phytate content were expected, since no plants were grown. The decrease in the Residual-P and the increase in $\mathrm{P}_{\mathrm{o}}$ pools is an indication that recalcitrant $\mathrm{P}_{\mathrm{o}}$ forms from Residual-P changed to less recalcitrant $\mathrm{P}$ forms in the $\mathrm{P}_{\mathrm{o}}$ pools. These changes could turn phytate or other recalcitrant organic compounds to forms more accessible by phytases, increasing the $\mathrm{P}_{\text {Phy-lab. }}$ Although the interaction of phytate with inorganic soil compounds has been much studied, less is known about phytate interactions with the soil organic compounds (Nanny \& Minear, 1994). The increased $P_{\text {Phy-lab }}$ could indicate an important possible way to further improve $P$ nutrition of subsequent crops. If soybean or grasses had mechanisms to a higher access the 
$\mathrm{P}_{\text {Phy-lab }}$ pool, possibly even higher increases in soybean $\mathrm{P}$ uptake and dry mass could have been observed.

In the soil with high $\mathrm{P}$ level, a possible competition of grass roots with microorganisms occurred, since MBP was lower in the soil cultivated with grasses than in the control (Table 4). The MBP was higher in the high $\mathrm{P}$ control than in the low $\mathrm{P}$ control, indicating that $\mathrm{P}$ is a limiting nutrient for the microbes in these soils.

\section{Inorganic phosphorus lability and desorption kinetics}

The low Total-P content observed in the present study is in agreement with the range of Total-P observed in similar weathered soils from Cerrado by Chapuis-Lardy et al. (2001), from 301 to $456 \mathrm{mg} / \mathrm{kg}$ in natural and pasture soils, respectively. Because of low Total-P content and high adsorption $\mathrm{P}$ capacity, the most labile $\mathrm{P}$ pools are low, and the $\mathrm{P}_{\mathrm{DET}}$ in the low-P soil was below the limit of detection by the malachite green method $(1 \mu \mathrm{g} / \mathrm{L})$. Since the $\mathrm{P}_{\mathrm{DET}}$ was not measured, it was not possible to calculate a series of other parameters, such as $K_{d}, R, R-R_{d i f f}$, and $T_{c}$, for the soil with low P level. Therefore, Table 5 shows only results of these parameters for soil with high P level.

The contrasting differences observed in Resin- $\mathrm{P}, \mathrm{P}_{\mathrm{DGT}}$, and $\mathrm{P}_{\mathrm{E}}$ is not a surprise (Mason et al., 2010). In the present study, $\mathrm{P}$ concentration extracted with resin was lower than the control treatment in the high-P soil; however, no differences were related to soybean plants grown on soil previously cultivated or not with grass, in the soil with high $\mathrm{P}$ level (Table 5). In soil with a lower P level, Resin-P was also not related with soybean response to $\mathrm{P}$ availability. In the high $\mathrm{P}$ soil, the results obtained with DGT corresponded with the response of soybean to $\mathrm{P}$, which indicates a higher accuracy of this method to predict $\mathrm{P}$ availability than resin (Mason et al., 2010). However, in the low-P soil, $\mathrm{P}_{\mathrm{E}}$ was negatively affected by grasses, while soybean P uptake was higher after grasses than in the control. This

This article is protected by copyright. All rights reserved. 
contrasting response of soybean plants and $\mathrm{P}_{\mathrm{E}}$ may be a consequence of the different mechanisms to induce $\mathrm{P}$ mobilization by soybean plants, as root exudation and microbial growth stimulation (Hinsinger, 2001; Richardson et al., 2001), and also due to P release from cover crop residues (Horst et al., 2001).

The calculated ratio $(\mathrm{R})$ between $\mathrm{P}_{\mathrm{DGT}}$ and $\mathrm{P}_{\mathrm{DET}}$ resulted in higher values than the most part of soils analyzed by Menezes-Blackburn et al. (2016b), meaning that in this highly weathered soil, the contribution of $\mathrm{P}_{\mathrm{i}}$ diffusion is small compared with the replenishment of pore water $\mathrm{P}_{\mathrm{i}}$, due to its desorption from the solid phase. The $\mathrm{R}_{\text {diff }}$ is the hypothetical ratio of the $\mathrm{P}_{\mathrm{DGT}}$ to the concentration in the soil solution if no resupply occurs (only pore water $\mathrm{P}$ diffusion). Since $\mathrm{R}_{\text {diff }}$ was low, $\mathrm{R}-\mathrm{R}_{\text {diff }}$ was the dominant component on plant $\mathrm{P}$ bioavailability. Surprisingly, $\mathrm{T}_{\mathrm{c}}$ values were low, and also different from those of the temperate soil samples analyzed by Menezes-Blackburn et al. (2016b), underlying the importance soil-P buffering capacity in this system. The soil used in this study has a very interesting $\mathrm{P}$ desorption behavior, because while soil solution $\mathrm{P}$ is low, $\mathrm{P}$ resupply to soil solution is fast, evidenced by the high $\mathrm{K}_{\mathrm{d}}$. This suggests that these soils can adsorb a high amount of $\mathrm{P}$ with low energy, despite oxisols being known to have a very high $\mathrm{P}$ sorption capacity. Nevertheless, it is worth noticing that the experimental soil has more than $60 \%$ of sand particles, which may have contributed to the low $\mathrm{P}$ adsorption energy.

As observed by Nunes et al. (2008), Guinea grass has a high P demand. Growing Guinea grass resulted in a lower content of $\mathrm{P}_{\mathrm{DET}}$ than the other species in the high $\mathrm{P}$ soil, and consequently, $\mathrm{P}$ availability was even more dependent from the resupply from the solid phase, and the sorption rate constant was 10 times higher in the soil cultivated with Guinea grass than with the other species. However, the decrease in $\mathrm{P}_{\mathrm{DET}}$ resulted in an increased gradient between the soil $\mathrm{P}$ in solution and the solid phase $\left(\mathrm{K}_{\mathrm{d}}\right)$, leading to a much smaller $\mathrm{T}_{\mathrm{c}}$.

This article is protected by copyright. All rights reserved. 


\section{Plant growth and phosphorus uptake}

Soil P was a limiting factor only to Guinea grass, which makes sense because ruzi grass and palisade grass are better adapted to P-poor soils (Rao et al., 1996). In the high $\mathrm{P}$ soil, the smaller dry mass of Guinea grass compared with ruzi grass and palisade grass was probably due to the lower P uptake (Table 6). The higher demand for P by Guinea grass than the Urochloa species is possibly due to its low capacity to mobilize less labile P forms.

Several plant species have been reported to exude compounds that increase soil $\mathrm{P}$ bioavailability into the rhizosphere, due to solubilization and mineralization of $\mathrm{P}_{\mathrm{o}}$, such organic acids and phosphatases (Hinsinger, 2001). It has been reported that ruzi grass and palisade grass are able to exude high amounts of organic acids (Ishikawa et al., 2000) that may stimulate rhizosphere microorganisms (Menezes-Blackburn et al., 2016a). Urochloa species are highly adapted to low soil P fertility, however, the mechanisms responsible need further research. Several soil microorganisms can produce phosphatases, and the relationship between plants and these microorganisms is important in the soil $\mathrm{P}$ cycle, in order for plants to acquire $\mathrm{P}$ from soil recalcitrant $\mathrm{P}$ sources (Richardson et al., 2001). According to Hayes et al. (2000), extractable $\mathrm{P}_{\mathrm{o}}$ increases with citric acid concentration, which could enhance $\mathrm{P}$ availability in the rhizosphere. Guinea grass seems to not be able to feed rhizosphere microorganisms as the other species, which also accounts for a lower shoot $\mathrm{P}$ accumulation in this species. The DIFS derived parameters also reflect the higher P demand by Guinea grass, depleting $\mathrm{P}$ in the soil solution, impairing plant $\mathrm{P}$ acquisition and $\mathrm{P}$ resupply, and eventually limiting the proliferation of microorganisms due to $\mathrm{P}$ competition.

There was no difference in the total $\mathrm{P}$ released from the straw of palisade grass and the other grasses (Table 6). The $\mathrm{P}$ re-mobilization by grasses, which resulted in the decrease of the Residual-P and supply of P during the grass straw decomposition, seems to be the factor responsible for the higher soybean dry matter yield and P uptake than in the soil kept 
fallow, as observed by Horst et al. (2001) growing Lablab purpureus. According to Canellas et al. (2004), the addition of crop residues on the soil surface results in increased soil diester $\mathrm{P}$, which is considered a labile $\mathrm{P}$ form. This effect was observed only in the low-P soil, indicating that $\mathrm{P}$ fertilizer application created a $\mathrm{P}$ sufficiency condition that overcame the effect of grasses in increasing P bioavailability to soybean. In the soil with high P level, even with the $\mathrm{P}$ re-mobilization due to grass growth, and the large increase of the Residual-P in the control treatment, soybean P uptake was not affected. The large differences in DIFS derived parameters observed between grass species in the soil with high $\mathrm{P}$ level were not reflected in differences in soybean $\mathrm{P}$ uptake, since this soil shows a high capacity to resupply $\mathrm{P}$ to soil solution.

Almeida \& Rosolem (2016) have shown that ruzigrass increases labile soil P forms in the long-term; however, the authors were not able to determine if the increase resulted either from changes in the less labile $\mathrm{P}$ pools or by deposition of $\mathrm{P}$ from ruzigrass residues. In the present study, analyzing the grasses effects in the short-term, the contribution of $\mathrm{P}$ deposition from grass residues seems to be the main factor improving $\mathrm{P}$ availability to soybean in low-P soil. A closer look into P dynamics in the rhizosphere of tropical grasses revealed a depletion of labile $\mathrm{P}$ forms, which may result in higher $\mathrm{P}$ adsorption capacity and lower soil P desorption, as observed by Almeida et al. (2018) and also here through a lower $\mathrm{P}_{\mathrm{E}}$ concentration in low-P soil. According to Almeida et al. (2018), ruzigrass should result in the accumulation of recalcitrant $\mathrm{P}_{\mathrm{o}}$ forms in soil. In the present study, it was observed that tropical grasses and microorganisms may expose recalcitrant $\mathrm{P}_{\mathrm{o}}$ forms, resulting in increased concentration of these $\mathrm{P}_{\mathrm{o}}$ forms, and showing that a great improvement in $\mathrm{P}$ availability may depend not only on the release of $\mathrm{P}$ from grass residues, but also on the mineralization of recalcitrant $\mathrm{P}_{\mathrm{o}}$ forms such as phytate.

This article is protected by copyright. All rights reserved. 


\section{Conclusions}

The soil $\mathrm{P}$ pool distribution is highly affected by tropical grasses grown as cover crops. Ruzi grass, palisade grass or Guinea grass increased $\mathrm{P}$ cycling, decreasing the less available $\mathrm{P}$ forms, regardless of soil initial $\mathrm{P}$ level. Grasses seems to solubilize recalcitrant $\mathrm{P}_{\mathrm{o}}$ forms, exposing phytates, and consequently increasing non-labile $\mathrm{P}$ concentration. The soil used in this study showed a capacity to resupply $\mathrm{P}$ to soil solution quickly, even with a very high $\mathrm{P}$ sorption. Nevertheless, changes in P desorption kinetics did not seem to explain the observed differences in P uptake by soybean.

The supply of $\mathrm{P}$ by decomposition of grass residues is the key factor to improve soybean P nutrition, and consequently increase soybean yield. When the soil P concentration is higher due to $\mathrm{P}$ fertilizer application, no clear advantages in soybean $\mathrm{P}$ nutrition were observed when in rotation with these grasses, rejecting the hypothesis that grass species improve the subsequent soybean $\mathrm{P}$ uptake in high-P soil.

\section{Acknowledgments}

This research was supported by São Paulo Research Foundation (FAPESP) grants \#2014/23707-5 and \#2015/04200-0, and was performed as part of the Organic Phosphorus Utilization in Soils (OPUS) project, funded by Biotechnology and Biological Sciences Research Council (BBSRC) responsive mode grant (BB/K018167/1) in the UK.

This article is protected by copyright. All rights reserved. 


\section{References}

Almeida, D.S., Penn, C.J. \& Rosolem, C.A. 2018. Assessment of phosphorus availability in soil cultivated with ruzigrass. Geoderma, 312, 64-73.

Almeida, D.S. \& Rosolem, C.A. 2016. Ruzigrass grown in rotation with soybean increases soil labile phosphorus. Agronomy Journal, 108, 1-9.

Beck, M.A. \& Sanchez, P.A. 1994. Soil phosphorus fraction dynamics during 18 years of cultivation on a typic Paleudult. Soil Science Society of America Journal, 58, 14241431.

Berg, A.S. \& Joern, B.C. 2006. Sorption dynamics of organic and inorganic phosphorus compounds in soil. Journal of Environmental Quality, 35, 1855-1862.

Calegari, A., Tiecher, T., Hargrove, W.L., Ralisch, R., Tessier, D., de Tourdonnet, S., Guimarães, M.d.F. \& dos Santos, D.R. 2013. Long-term effect of different soil management systems and winter crops on soil acidity and vertical distribution of nutrients in a Brazilian Oxisol. Soil and Tillage Research, 133, 32-39.

Canellas, L.P., Espíndola, J.A.A., Guerra, J.G.M., Teixeira, M.G., Velloso, A.C.X. \& Rumjanek, V.M. 2004. Phosphorus analysis in soil under herbaceous perennial leguminous cover by nuclear magnetic spectroscopy. Pesquisa Agropecuária Brasileira, 39, 589-596.

Chapuis-Lardy, L., Brossard, M. \& Quiquampoix, H. 2001. Assessing organic phosphorus status of Cerrado oxisols (Brazil) using 31P-NMR spectroscopy and phosphomonoesterase activity measurement. Canadian Journal of Soil Science, 81, 591-601.

Condron, L.M. \& Goh, K.M. 1989. Effects of long-term phosphatic fertilizer applications on amounts and forms of phosphorus in soils under irrigated pasture in New Zealand. Journal of Soil Science, 40, 383-395.

Cross, A.F. \& Schlesinger, W.H. 1995. A literature review and evaluation of the Hedley fractionation: applications to the biogeochemical cycle of soil phosphorus in natural ecosystems. Geoderma, 64, 197-214.

Harper, M.P., Davison, W. \& Tych, W. 2000. DIFS - A modelling and simulation tool for DGT induced trace metal remobilisation in sediments and soils. Environmental Modelling \& Software, 15, 55-66.

Hayes, J.E., Richardson, A.E. \& Simpson, R.J. 2000. Components of organic phosphorus in soil extracts that are hydrolysed by phytase and acid phosphatase. Biology and Fertility of Soils, 32, 279-286.

Hedley, M.J., Stewart, J.W.B. \& Chauhan, B.S. 1982. Changes in inorganic and organic soil phosphorus fractions induced by cultivation practices and by laboratory incubations. Soil Science Society of America Journal, 46, 970-976.

Hinsinger, P. 2001. Bioavailability of soil inorganic P in the rhizosphere as affected by rootinduced chemical changes: A review. Plant and Soil, 237, 173-195.

Horst, W.J., Kamh, M., Jibrin, J.M. \& Chude, V.O. 2001. Agronomic measures for increasing $\mathrm{P}$ availability to crops. Plant and Soil, 237, 211-223.

Ishikawa, S., Wagatsuma, T., Sasaki, R. \& Ofei-Manu, P. 2000. Comparison of the amount of citric and malic acids in $\mathrm{Al}$ media of seven plant species and two cultivars each in five plant species. Soil Science and Plant Nutrition, 46, 751-758.

Jackson, M.L. 1973. Soil chemical analysis, Prentice Hall of India New Delhi.

Macklon, A.E.S., Grayston, S.J., Shand, C.A., Sim, A., Sellars, S. \& Ord, B.G. 1997. Uptake and transport of phosphorus by Agrostis capillaris seedlings from rapidly hydrolysed organic sources extracted from 32 P-labelled bacterial cultures. Plant and Soil, 190, 163-167.

This article is protected by copyright. All rights reserved. 
Mason, S., McNeill, A., McLaughlin, M.J. \& Zhang, H. 2010. Prediction of wheat response to an application of phosphorus under field conditions using diffusive gradients in thin-films (DGT) and extraction methods. Plant and Soil, 337, 243-258.

Menezes-Blackburn, D., Paredes, C., Zhang, H., Giles, C.D., Darch, T., Stutter, M., George, T.S., Shand, C., Lumsdon, D., Cooper, P., Wendler, R., Brown, L., Blackwell, M., Wearing, C. \& Haygarth, P.M. 2016a. Organic acids regulation of chemical-microbial phosphorus transformations in soils. Environmental Science \& Technology, 50, 11521-11531.

Menezes-Blackburn, D., Zhang, H., Stutter, M., Giles, C.D., Darch, T., George, T.S., Shand, C., Lumsdon, D., Blackwell, M., Wearing, C., Cooper, P., Wendler, R., Brown, L. \& Haygarth, P.M. 2016b. A holistic approach to understanding the desorption of phosphorus in soils. Environmental Science \& Technology, 50, 3371-3381.

Merlin, A., Rosolem, C.A. \& He, Z.L. 2015. Non-labile phosphorus acquisition by Brachiaria. Journal of Plant Nutrition, 39, 1319-1327.

Nanny, M.A. \& Minear, R.A. 1994. Organic phosphorus in the hydrosphere. In: Environmental chemistry of lakes and reservoirs. American Chemical Society, Washington, DC, pp. 161-191.

Nunes, F.N., Cantarutti, R.B., Novais, R.F., Silva, I.R.d., Tótola, M.R. \& Ribeiro, B.N. 2008. Atividade de fosfatases em gramíneas forrageiras em resposta à disponibilidade de fósforo no solo e à altura de corte das plantas. Revista Brasileira de Ciência do Solo, 32, 1899-1909.

Raghothama, K.G. \& Karthikeyan, A.S. 2005. Phosphate acquisition. Plant and Soil, 274, 3749.

Raij, B., Andrade, J.C., Cantarella, H. \& Quaggio, J.A. 2001. Análise química para avaliação da fertilidade de solos tropicais, Instituto Agronômico, Campinas.

Rao, I.M., Kerridge, P.C. \& Macedo, M.C.M. 1996. Nutritional requirements of Brachiaria and adaptation to acid soils. In: Brachiaria: Biology, Agronomy and Improvement. (eds J.W. Miles, B.L. Maass \& C.B. do Valle), CIAT/EMBRAPA, Cali/Brasília, pp. 53-71.

Richardson, A.E., Hadobas, P.A., Hayes, J.E., O'Hara, C.P. \& Simpson, R.J. 2001. Utilization of phosphorus by pasture plants supplied with myo-inositol hexaphosphate is enhanced by the presence of soil micro-organisms. Plant and Soil, 229, 47-56.

Rodrigues, M., Pavinato, P.S., Withers, P.J.A., Teles, A.P.B. \& Herrera, W.F.B. 2016. Legacy phosphorus and no tillage agriculture in tropical oxisols of the Brazilian savanna. Science of the Total Environment, 542, 1050-1061.

Roose, T. \& Kirk, G.J.D. 2009. The solution of convection-diffusion equations for solute transport to plant roots. Plant and Soil, 316, 257-264.

Shears, S.B. \& Turner, B.L. 2007. Nomenclature and terminology of inositol phosphates: clarification and a glossary of terms. In: Inositol phosphates: Linking agriculture and the environment. (eds B.L. Turner, A.E. Richardson \& E.J. Mullaney), CAB International, Wallingford, UK, pp. 1-6.

Soil Survey Staff (2014) Keys to soil taxonomy, 12th ed. Keys to soil taxonomy. USDANatural Resources Conservation Service.

Stutter, M.I., Shand, C.A., George, T.S., Blackwell, M.S.A., Dixon, L., Bol, R., MacKay, R.L., Richardson, A.E., Condron, L.M. \& Haygarth, P.M. 2015. Land use and soil factors affecting accumulation of phosphorus species in temperate soils. Geoderma, 257-258, 29-39.

Syers, J., Johnston, A. \& Curtin, D. 2008. Efficiency of soil and fertilizer phosphorus use Reconciling changing concepts of soil phosphorus behaviour with agronomic information, FAO, United Nations, ROME.

This article is protected by copyright. All rights reserved. 
Zhang, H. \& Davison, W. 1995. Performance characteristics of diffusion gradients in thin films for the in situ measurement of trace metals in aqueous solution. Analytical Chemistry, 67, 3391-3400.

Zhang, H., Zhao, F.-J., Sun, B., Davison, W. \& McGrath, S.P. 2001. A new method to measure effective soil solution concentration predicts copper availability to plants. Environmental Science \& Technology, 35, 2602-2607.

Table 1 Selected chemical characteristics of initial soil samples collected before grasses grown, as a function of soil phosphorus $(\mathrm{P})$ level.

\begin{tabular}{lcc}
\hline & \multicolumn{3}{c}{ Soil P level } \\
& Low P & High P \\
level & level \\
\hline \multicolumn{3}{c}{ Chemical soil characterization } \\
$\mathrm{pH}^{\mathrm{a}}$ & 5.5 & 5.7 \\
& $------\mathrm{mg} / \mathrm{kg}$ & ------ \\
$\mathrm{Resin}-\mathrm{P}^{\mathrm{b}}$ & 8 & 19 \\
$\mathrm{SOM}^{\mathrm{c}}$ & $-------\mathrm{g} / \mathrm{kg}------$ \\
& 19 & 18 \\
$\mathrm{H}+\mathrm{Al}^{\mathrm{d}}$ & $-----\mathrm{mmol}_{\mathrm{c}} / \mathrm{kg}----$ \\
$\mathrm{K}$ & 12.5 & 13.2 \\
$\mathrm{Ca}$ & 2.0 & 1.1 \\
$\mathrm{Mg}$ & 24 & 22 \\
$\mathrm{CEC}$ & 0.16 & 0.14 \\
$\mathrm{SOil}$ & 39 & 36 \\
\hline
\end{tabular}

${ }^{\mathrm{a}} \mathrm{Soil} \mathrm{pH}$ measured in calcium chloride solution.

${ }^{\mathrm{b}}$ Phosphorus extracted with pearl resin.

${ }^{c}$ Soil organic matter.

${ }^{\mathrm{d}}$ Potential acidity.

${ }^{\mathrm{e}}$ Cation exchange capacity. 
Table 2 Changes $(\Delta)$ in soil phosphorus (P) fractions content between soils sampled before (Time 0) and after grasses growth, as a function of soil $\mathrm{P}$ level and grass species, and a control treatment with soil kept fallow.

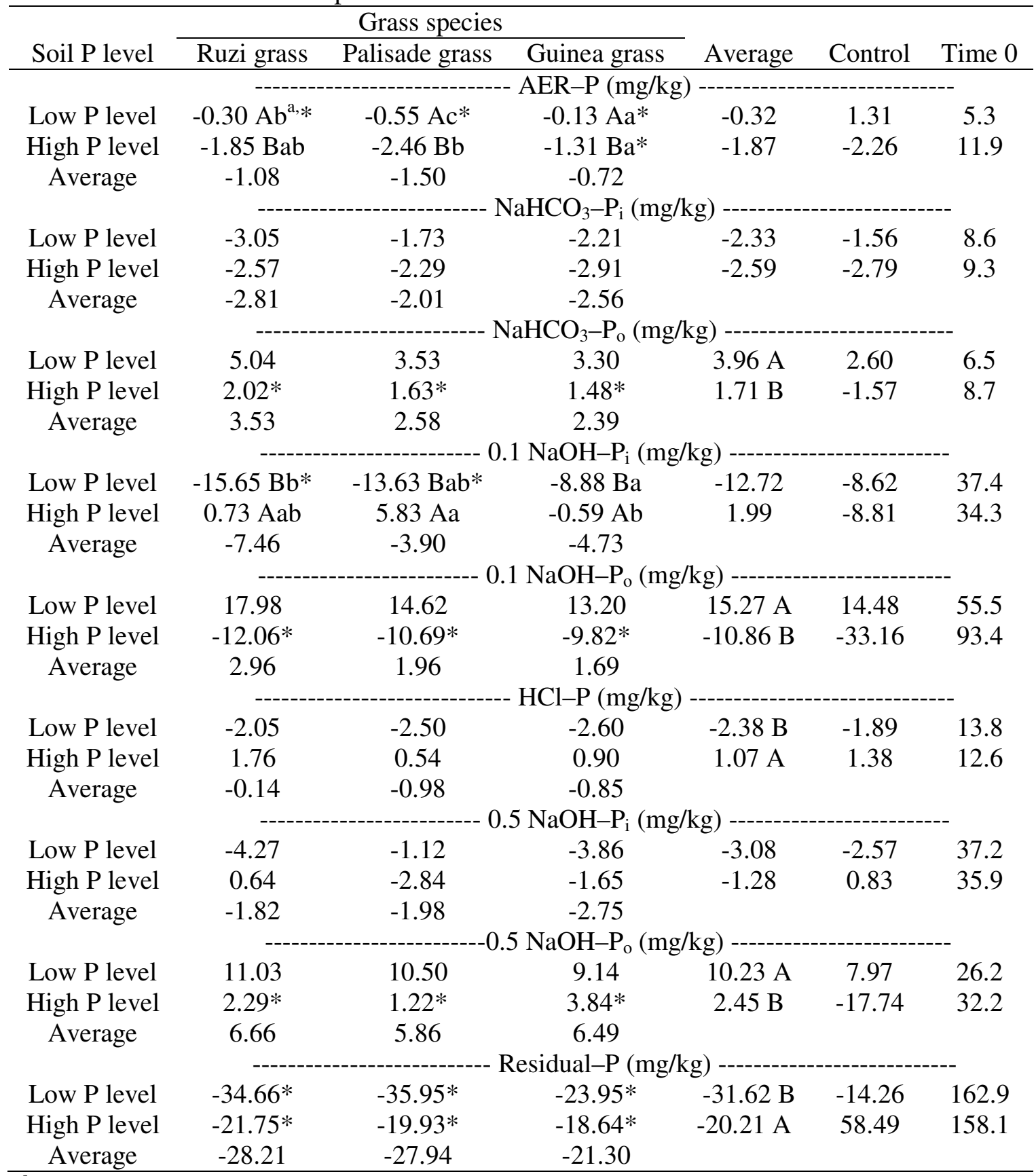

${ }^{\mathrm{a}}$ Average followed by the same lowercase letter in the line and uppercase in the column were not significantly different, as a function of soil P level and grass species (Tukey, $p<0.05$ );

*Indicates a significant difference between each treatment and the control treatment (Dunnett, $p<0.05)$.

This article is protected by copyright. All rights reserved. 
Table 3 Changes $(\Delta)$ in soil phosphorus $(\mathrm{P})$ concentration extracted with sodium hydroxide and Ethylenediaminetetraacetic acid $(\mathrm{NaOH}-\mathrm{EDTA})$, and soil phytase labile $\mathrm{P}$ ( $\left.\mathrm{P}_{\text {phy-lab}}\right)$ concentration and changes in percentage of $\mathrm{P}_{\text {phy-lab }}$ according to organic $\mathrm{P}$ extracted with $\mathrm{NaOH}-\mathrm{EDTA}$ ( $\mathrm{NaOH}-\mathrm{EDTA}-\mathrm{P}_{\mathrm{o}}$ ). Changes calculated between soils sampled before (Time 0 ) and after grasses growth, as affected by soil $\mathrm{P}$ level and grass species, and a control treatment with soil kept fallow.

\begin{tabular}{|c|c|c|c|c|c|c|}
\hline \multirow[b]{2}{*}{ Soil P level } & \multicolumn{3}{|c|}{ Grass species } & \multirow[b]{2}{*}{ Average } & \multirow[b]{2}{*}{ Control } & \multirow[b]{2}{*}{ Time 0} \\
\hline & Ruzi grass & Palisade grass & Guinea grass & & & \\
\hline & \multicolumn{6}{|c|}{ - } \\
\hline Low P level & -3.36 & -1.70 & -1.42 & $-2.16 \mathrm{~A}^{\mathrm{a}}$ & -2.61 & 25.9 \\
\hline High P level & -14.08 & -13.08 & -13.11 & $-13.42 \mathrm{~B}$ & -14.00 & 50.9 \\
\hline Average & -8.72 & -7.39 & -7.26 & & & \\
\hline & & $\mathrm{Na}$ & $\mathrm{H}$-EDTA-P ${ }_{\mathrm{o}}$ & g/kg) ---- & & --- \\
\hline Low P level & 1.07 & 1.66 & 1.25 & $1.33 \mathrm{~A}$ & 2.28 & 39.6 \\
\hline High P level & -2.11 & -3.71 & -5.47 & $-3.76 \mathrm{~B}$ & -2.70 & 58.6 \\
\hline Average & -0.52 & -1.03 & -2.11 & & & \\
\hline & & 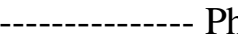 & tase labile P ( & /kg) ---- & & \\
\hline Low P level & $5.46 \mathrm{Aa}$ & $3.72 \mathrm{Aab}$ & $2.48 \mathrm{Bb}$ & 3.73 & 5.32 & 5.24 \\
\hline High P level & $3.17 \mathrm{Aa}$ & $4.77 \mathrm{Aa}$ & $5.30 \mathrm{Aa}$ & 4.41 & 3.31 & 3.44 \\
\hline Average & 4.31 & 4.24 & 3.66 & & & \\
\hline Low P level & $9.87 \mathrm{Aa}$ & $721 \mathrm{Aab}$ & $\begin{array}{c}\text { hytase labile P } \\
447 \mathrm{Ab}^{*}\end{array}$ & 7.19 & 982 & 1323 \\
\hline High P level & $7.45 \mathrm{Ab}$ & 10.97 Aab & $12.52 \mathrm{Ba}^{*}$ & 10.31 & 7.21 & 5.87 \\
\hline Average & 8.66 & 9.09 & 8.50 & & & \\
\hline
\end{tabular}

${ }^{a}$ Average followed by the same lowercase letter in the line and uppercase in the column were not significantly different, as a function of soil P level and grass species (Tukey, $p<0.05$ ); *Indicates a significant difference between each treatment and the control treatment (Dunnett, $p<0.05)$.

This article is protected by copyright. All rights reserved. 
Table 4 Microbial biomass phosphorus (P), as affected by soil P level and grass species, and a control treatment with soil kept fallow.

\begin{tabular}{|c|c|c|c|c|c|}
\hline \multirow[b]{2}{*}{ Soil P level } & \multicolumn{3}{|c|}{ Grass species } & \multirow[b]{2}{*}{ Average } & \multirow[b]{2}{*}{ Control } \\
\hline & Ruzi grass & Palisade grass & Guinea grass & & \\
\hline & \multicolumn{5}{|c|}{ 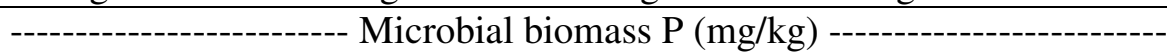 } \\
\hline Low P level & 0.63 & 0.54 & 0.51 & 0.57 & 0.60 \\
\hline High P level & $0.70 *$ & $0.66^{*}$ & $0.42 *$ & 0.72 & 1.15 \\
\hline Average & $0.67 \mathrm{a}^{\mathrm{a}}$ & $0.60 \mathrm{ab}$ & $0.44 \mathrm{~b}$ & & \\
\hline
\end{tabular}

Table 5 Soil available phosphorus $(\mathrm{P})$ extracted with pearl resin (Resin-P), labile $\mathrm{P}\left(\mathrm{P}_{\mathrm{DGT}}\right)$ and effective phosphorus concentration $\left(\mathrm{P}_{\mathrm{E}}\right)$, as affected by soil $\mathrm{P}$ level and grass species, and a control treatment with soil kept fallow. Soil solution $\mathrm{P}\left(\mathrm{P}_{\mathrm{DET}}\right)$, resupply potential $\left(\mathrm{K}_{\mathrm{d}}\right)$, and response time of the system $\left(\mathrm{T}_{\mathrm{c}}\right)$ as a function of grass species, and a control treatment with soil kept fallow, in soil with high $\mathrm{P}$ level.

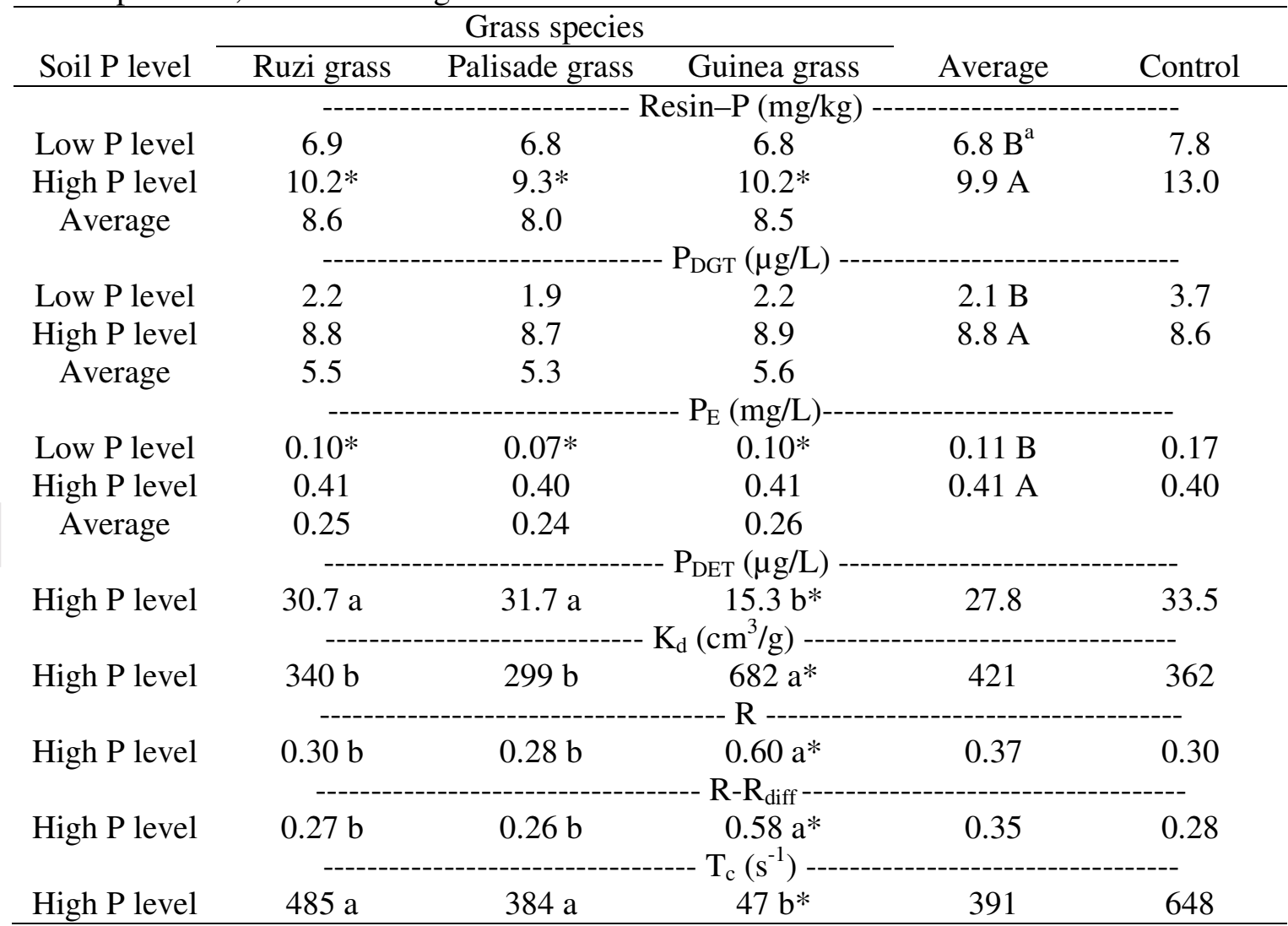

${ }^{a}$ Average followed by the same lowercase letter in the line and uppercase in the column were not significantly different, as a function of soil P level and grass species (Tukey, $p<0.05$ ); *Indicates a significant difference between each treatment and the control treatment (Dunnett, $p<0.05)$.

This article is protected by copyright. All rights reserved. 
Table 6 Grass shoot, root, and total dry matter, grass shoot phosphorus (P) uptake before desiccation, $\mathrm{P}$ release from grass straw 60 days after desiccation, and decomposition of grasses straw, as affected by soil P level and grass species. Soybean shoot dry matter and shoot $\mathrm{P}$ uptake, as affected by soil $\mathrm{P}$ level and grass species, and a control treatment with soil kept fallow.

\begin{tabular}{|c|c|c|c|c|c|}
\hline \multirow[b]{2}{*}{ Soil P level } & \multicolumn{3}{|c|}{ Grass species } & \multirow[b]{2}{*}{ Average } & \multirow[b]{2}{*}{ Control } \\
\hline & Ruzi grass & Palisade grass & Guinea grass & & \\
\hline & \multicolumn{5}{|c|}{------------------- Grasses shoot dry matter (g/pot) ------------------ } \\
\hline Low P level & 22.8 & 22.3 & 19.3 & 21.5 & - \\
\hline High P level & 22.2 & 21.9 & 21.0 & 21.7 & - \\
\hline \multirow[t]{2}{*}{ Average } & $22.5 \mathrm{a}^{\mathrm{a}}$ & $22.1 \mathrm{a}$ & $20.2 \mathrm{~b}$ & & \\
\hline & \multicolumn{5}{|c|}{ 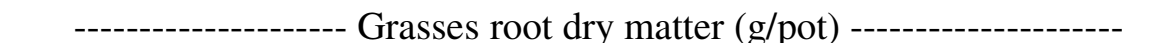 } \\
\hline Low P level & 8.4 & 9.1 & 7.9 & $8.5 \mathrm{~B}$ & - \\
\hline High P level & 11.6 & 10.7 & 10.1 & $10.8 \mathrm{~A}$ & - \\
\hline \multirow[t]{2}{*}{ Average } & 10.0 & 9.9 & 9.0 & & \\
\hline & \multicolumn{5}{|c|}{ Grasses total dry matter (g/pot) } \\
\hline Low P level & $31.2 \mathrm{Aa}$ & $31.4 \mathrm{Aa}$ & $27.1 \mathrm{Bb}$ & 29.9 & - \\
\hline High P level & $33.7 \mathrm{Aa}$ & $32.6 \mathrm{Aa}$ & $31.13 \mathrm{Ab}$ & 32.5 & - \\
\hline \multirow[t]{2}{*}{ Average } & 32.5 & 32.0 & 29.2 & & \\
\hline & \multicolumn{5}{|c|}{ - Grasses shoot P uptake (mg/pot) - } \\
\hline Low P level & $23.0 \mathrm{Ba}$ & $23.3 \mathrm{Ba}$ & $15.0 \mathrm{Bb}$ & 20.4 & - \\
\hline High P level & $30.6 \mathrm{Aa}$ & $33.4 \mathrm{Aa}$ & $29.4 \mathrm{Aa}$ & 31.1 & - \\
\hline \multirow[t]{2}{*}{ Average } & 26.8 & 28.3 & 22.2 & & \\
\hline & \multicolumn{5}{|c|}{ 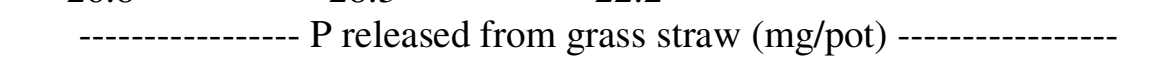 } \\
\hline Low P level & 5.12 & 4.98 & 2.06 & $4.05 \mathrm{~B}$ & - \\
\hline High P level & 5.78 & 6.26 & 6.24 & $6.09 \mathrm{~A}$ & - \\
\hline \multirow[t]{2}{*}{ Average } & 5.45 & 5.62 & 4.15 & & \\
\hline & \multicolumn{5}{|c|}{ - } \\
\hline Low P level & 32.3 & 23.9 & 31.4 & 29.2 & - \\
\hline High P level & 30.1 & 19.9 & 29.3 & 26.4 & - \\
\hline \multirow[t]{2}{*}{ Average } & $31.2 \mathrm{a}$ & $21.9 \mathrm{~b}$ & $30.4 \mathrm{a}$ & & \\
\hline & \multicolumn{5}{|l|}{-------- } \\
\hline Low P level & $10.2 \mathrm{Bb}^{*}$ & $13.7 \mathrm{Ba}^{*}$ & $11.2 \mathrm{Bab}^{*}$ & 11.7 & 7.0 \\
\hline High P level & $25.9 \mathrm{Aa}$ & $23.9 \mathrm{Aa}$ & $26.7 \mathrm{Aa}$ & 25.5 & 25.8 \\
\hline \multirow[t]{2}{*}{ Average } & 18.1 & 18.8 & 18.9 & & \\
\hline & \multicolumn{5}{|c|}{ - } \\
\hline Low P level & $16.9 *$ & $18.6^{*}$ & $16.3 *$ & $17.3 \mathrm{~B}$ & 12.7 \\
\hline High P level & 39.0 & 37.3 & 39.1 & $38.5 \mathrm{~A}$ & 39.3 \\
\hline Average & 27.5 & 28.0 & 27.6 & & \\
\hline
\end{tabular}

${ }^{a}$ Average followed by the same lowercase letter in the line and uppercase in the column were not significantly different, as a function of soil P level and grass species (Tukey, $p<0.05$ ); *Indicates a significant difference between each treatment and the control treatment (Dunnett, $p<0.05)$.

This article is protected by copyright. All rights reserved. 